\section{Surgical management of pediatric Cushing's disease: an analysis of 15 consecutive cases at a specialized neurosurgical center}

\author{
Estratégia cirúrgica na doença de Cushing em pacientes \\ pediátricos: análise de 15 casos consecutivos operados \\ em centro neurocirúrgico especializado
}

Ricardo Santos de Oliveira', Margaret de Castro' ${ }^{2}$ Sonir Roberto Rauber Antonini², Carlos Eduardo Martinelli Júnior², Ayrton Custódio Moreira², Helio Rubens Machado'
1 Divisão de Neurocirurgia Pediátrica, Departamento de Cirurgia e Anatomia, Faculdade de Medicina de Ribeirão Preto (FMRP), Universidade de São Paulo (USP), Ribeirão Preto, SP, Brasil 2 Divisão de Endocrinologia, FMRP-USP, Ribeirão Preto, SP, Brasil clinical adrenal insufficiency and serum cortisol levels were below $18 \mu \mathrm{g} / \mathrm{dL}$ or $50 \mathrm{nmol}$ after one two three, or seven days following surgery; they therefore required cortisone replacement therapy. Follow-up was for a median time of 11.5 years (range: 2 to 25 years). Results: Clinical and biochemical cure was achieved in $9 / 15$ patients $(60 \%)$ exclusively after transsphenoidal surgery. Hypopituitarism was observed in four patients; growth hormone deficiency, in two; permanent diabetes insipidus, in one case. Conclusions: Cushing's disease is rare in children and adolescents. Transsphenoidal surgery is an effective and safe treatment in most of these patients. Plasma cortisol level $<1.8 \mu \mathrm{g} / \mathrm{dL}$ following surgery is the treatment goal and is a good predictive factor for long-term cure of Cushing's disease. Arq Bras Endocrinol Metab. 2010;54(1):17-23

\title{
Keywords
}

Cushing's disease; pituitary tumor; transsphenoidal surgery; pediatric neurosurgery

\section{RESUMO}

Objetivo: O objetivo deste estudo foi avaliar os resultados cirúrgicos em pacientes pediátricos com doença de Cushing com idade inferior a 18 anos, submetidos à cirurgia transfenoidal num centro especializado, durante um período de acompanhamento de 25 anos. Sujeitos e métodos: Estudo retrospectivo dos prontuários médicos de 15 pacientes pediátricos com doença de Cushing (idade média de 13 anos), sendo avaliados aspectos clínicos, laboratoriais, histológicos e radiológicos. Todos os pacientes foram avaliados pela mesma equipe de endocrinologistas e operados por um mesmo neurocirurgião, entre 1982 e 2006 . 0 tempo médio de seguimento foi 11,5 anos (2 a 25 anos). Os pacientes foram considerados curados quando houve insuficiência adrenal e níveis de cortisol plasmático inferiores a 1,8 $\mu \mathrm{g} / \mathrm{dL}$ ou $50 \mathrm{nmol} / \mathrm{L}$ no pós-operatório um, dois, três ou sete dias após a cirurgia; estes pacientes necessitaram de reposição de corticosteroide. Resultados: Cura clínica e bioquímica foi alcançada em $9 / 15$ pacientes $(60 \%)$ após a cirurgia transfenoidal. Hipopituitarismo foi observado em quatro pacientes; déficit de hormônio de crescimento, em dois; diabetes insípido permanente, em um. Conclusões: A doença de Cushing é rara na infância e na adolescência. A cirurgia transfenoidal é um tratamento efetivo e seguro para a maioria dos pacientes. Uma concentração de cortisol plasmático $<1,8 \mu \mathrm{g} / \mathrm{dL}$ nos primeiros dias pós-cirurgia transfenoidal é o objetivo do tratamento e um fator preditivo tardio para a cura da doença de Cushing. Arq Bras Endocrinol Metab. 2010;54(1):17-23

Correspondence to: Ricardo Santos de Oliveira Divisão de Neurocirurgia Pediátrica, Departamento de Cirurgia e Anatomia, FMRP-USP,

Campus Universitário 14049-900 - Ribeirão Preto, SP, Brasil

rsoliveira@hcrp.fmrp.usp.br

Received on Apr/8/2009 Accepted on Sept/21/2009 


\section{INTRODUCTION}

Cushing's disease (CD) is a life-threatening con$\checkmark$ dition in children. It is characterized by hypersecretion of an adrenocorticotropic hormone (ACTH) secreting tumor, which causes chronic adrenal overproduction of cortisol (1). The main clinical features and some aspects of the management of pediatric patients with CD differ somewhat from those seen in adults. They include growth impairment, weight gain, hypertension and pubertal delay or arrest. Transsphenoidal surgery remains the mainstay of therapy; it allows removal of an ACTH-producing adenoma without the need for long-term replacement therapy, though cure rates vary (2-6). Surgical technical difficulties and posttherapy hypopituitarism can be more damaging for children than adults because growth and puberty are not yet complete $(4,7)$. We report on surgical management and outcome of the treatment of 15 pediatric CD patients, who had only been operated on by the same neurosurgeon over the last 25 years at a specialized center.

\section{SUBJECTS AND METHODS}

\section{Patients}

This study was approved by the Ethics Committee of the Hospital das Clínicas of the Faculdade de Medicina de Ribeirão Preto (FMRP) of Universidade de São Paulo (USP).

Medical records, imaging findings, and operative notes of 15 children younger than 18 years $(7$ males and 8 females), who were admitted consecutively to our service with CD from December 1982 to December 2006, were retrospectively reviewed. Patient age (mean \pm standard deviation, SD) at diagnosis was $13 \pm$ 2.9 years (range: 6 to 18 ). The mean duration of $C D$ was 3 years (range: 0.5 to 10 ). The main presenting features were weight gain (14/15), impaired growth (11/15), and hypertension (10/15). Abdominal striae, hirsutism, acne and amenorrhea were observed in 8,7 , 5 and 3 of the 15 patients, respectively.

All patients were evaluated by a multidisciplinary team, in which a neuroendocrinologist, a pediatric endocrinologist, and a pediatric neurosurgeon were included.

Diagnosis of CD was established by suggestive clinical findings, loss of plasma or salivary cortisol circadian rhythm and no suppression of cortisol levels after an overnight dexamethasone suppression test $(20 \mu \mathrm{g} / \mathrm{kg}$ up to $1 \mathrm{mg})(8,9)$. The pituitary etiology of hypercorti- solism (CD) was determined by measurement of plasma ACTH levels, high-dose and very high-dose dexamethasone suppression tests in all patients, and the corticotrophin releasing hormone $(\mathrm{CRH})$ test $(8)$. All patients had some preoperative imaging. Computed tomography (CT) was performed in ten patients and magnetic resonance (MR), in five cases. Five out of 15 patients had normal preoperative imaging; three of them performed CT. Bilateral inferior petrosal sinus sampling (BIPSS) for ACTH measure was performed in 2 of the 15 patients. Diagnosis of CD was confirmed by surgery and positive pituitary tissue pathology. Histological findings were divided into two groups: (i) obvious pituitary adenomas with ACTH staining in 12 cases and (ii) biopsies with high numbers of ACTH-staining cells without evidence of adenoma in 3 patients.

\section{Surgical approach and difficulties}

All operations were performed by the same neurosurgeon. The surgical technique and strategy described in detail by Hardy, in 1969, was followed (10). Briefly, resection of all presumed adenomas was performed via a sublabial, paraseptal, transsphenoidal approach. After exposition of the sellar region and incision in the dura the entire pituitary gland was carefully examined, and all abnormal tissue was excised. In patients with no clearly abnormal tissue, depending on age, history, and severity of disease, hemihypophysectomy, subtotal hypophysectomy, or, rarely, total hypophysectomy was performed. Aggressiveness of the surgery was individualized, considering patient characteristics, preoperative morbidity, severity of clinical symptoms, and recurrence of disease.

Fluoroscopy was especially helpful to reduce the risk of straying from the midline and injuring the carotid artery and cavernous sinus. An airpower drill (Midas $\operatorname{Rex}^{\circledR}$, Medtronic Neurological) was used to open the sphenoid sinus and reach the pituitary sella in three cases, because the sphenoid sinus aeration was absent.

\section{Outcome evaluation}

Patients were considered cured when there was clinical adrenal insufficiency and serum cortisol levels were $<50$ $\mathrm{nmol} / \mathrm{L}$ after one, two, three, or seven days following surgery; they therefore required cortisone replacement therapy. All patients returned to our neuroendocrine outpatient clinic at regular intervals for endocrinological evaluations. The mean follow-up period was 7.7 years (range: 2 to 25 ; median: 3.2 ). 


\section{RESULTS}

During the 25-year period, 15 children and adolescents with $\mathrm{CD}$ were treated with transsphenoidal surgery and followed up in the Hospital of Clinics of Ribeirão Preto, University of São Paulo (Table 1).

In this series, imaging correctly localized the adenoma within the pituitary fossa in ten patients $(66.6 \%)$, as confirmed by surgery. Eight of the 15 patients had a microadenoma; 2 had a macroadenoma; and 5 patients were normal in preoperative images. One patient (case 11) presented with a bilateral microadenoma in preope- rative MR. Two of the 15 patients (cases 12 and 14 ) underwent BIPSS, which successfully lateralized the lesion in both, and surgical cure was achieved after TSS.

In most patients a distinct tumor was visualized and excised. Adenomas were found in 12/15 patients based on histology (ACTH staining +); 3 patients presented high numbers of ACTH staining cells (hyperplasia) without evidence of adenoma.

Transsphenoidal excision of the corticotroph adenomas was performed in all patients. Clinical and/or biochemical cure was achieved in nine patients $(60 \%)$ exclusively after TSS; eight of them achieved both criteria and

Table 1. Surgical management of 15 consecutive pediatric patients with Cushing's disease

\begin{tabular}{|c|c|c|c|c|c|c|c|c|c|c|c|c|c|c|c|}
\hline $\begin{array}{l}\text { Case } \\
\text { No. }\end{array}$ & $\begin{array}{l}\text { Age (yrs) } \\
\text { at surgery/ } \\
\text { Sex }\end{array}$ & $\begin{array}{l}\text { Length of } \\
\text { history }\end{array}$ & $\begin{array}{c}\text { Neuroradiological } \\
\text { Features }\end{array}$ & BIPSS & $\begin{array}{c}\text { Initial } \\
\text { operative } \\
\text { approach }\end{array}$ & $\begin{array}{l}\text { Resec- } \\
\text { tion }\end{array}$ & Histology & $\begin{array}{l}\text { Post-op } \\
\text { serum } \\
\text { cortisol }\end{array}$ & $\begin{array}{l}\text { Surgical } \\
\text { cure }\end{array}$ & $\begin{array}{c}\text { Complemen- } \\
\text { tary } \\
\text { therapy }\end{array}$ & RT & ADX & Remission & Outcome & $\begin{array}{c}\text { FW } \\
\text { (yrs) }\end{array}$ \\
\hline 1 & $12 / \mathrm{M}$ & $8 \mathrm{mos}$ & normal CT & NA & TSS & partial & $\begin{array}{l}\text { adenoma } \\
\mathrm{ACTH}_{+}\end{array}$ & 7.2 & no & $2^{\text {nd }}$ TSS $†$ & yes & yes & yes & $\begin{array}{c}\text { DM } \\
\text { hypert }\end{array}$ & 25 \\
\hline 2 & $13 / M$ & $1 \mathrm{yr}$ & micro (CT) & NA & TSS $^{\ddagger}$ & total & $\begin{array}{l}\text { adenoma } \\
\mathrm{ACTH}_{+}\end{array}$ & $<1.2$ & yes & NA & no & no & NA & normal & 23 \\
\hline 3 & $18 / F$ & $15 \mathrm{mos}$ & micro (CT) & NA & TSS & total & $\begin{array}{l}\text { adenoma } \\
\mathrm{ACTH}_{+}\end{array}$ & $<1.2$ & yes & NA & no & no & NA & normal & 20 \\
\hline 4 & $12 / M$ & $5 \mathrm{yrs}$ & normal (CT) & NA & TSS & total & $\begin{array}{l}\text { adenoma } \\
\mathrm{ACTH}+\end{array}$ & 7.0 & no & $\begin{array}{c}2^{\text {nd }} \text { TSS } \\
\text { (Nelson's } \\
\text { Syndrome) }\end{array}$ & yes & yes & no & $\begin{array}{l}A P \text { in } \\
\text { reposition }\end{array}$ & 20 \\
\hline 5 & $14 / M$ & 4 yrs & normal (CT) & NA & TSS & total & $\begin{array}{l}\text { adenoma } \\
\mathrm{ACTH}_{+}\end{array}$ & $<1.2$ & yes & NA & no & no & NA & GH deficit & 20 \\
\hline 6 & $15 / F$ & $8 \mathrm{mos}$ & micro (CT) & NA & TSS & total & $\begin{array}{l}\text { adenoma } \\
\mathrm{ACTH}_{+}\end{array}$ & 22.4 & no & $\begin{array}{c}2^{\text {nd }} \text { TSS, } \\
3^{\text {rd }} \text { TSS } \\
\text { (Nelson's } \\
\text { Syndrome) }\end{array}$ & no & yes & no & death $\S$ & 3 \\
\hline 7 & $14 / F$ & 10 mos & micro (CT) & NA & TSS $^{*}$ & total & $\begin{array}{c}\text { adenoma } \\
\mathrm{ACTH}+, \mathrm{GH}_{+}\end{array}$ & 11.2 & no & $\begin{array}{c}2^{\text {nd }} \text { TSS, } \\
3^{\text {rd }} \text { TSS } \\
\text { (Nelson'S } \\
\text { Syndrome) }\end{array}$ & yes & yes & no & ketoconazole & 15 \\
\hline 8 & $12 / F$ & 3 yrs & $\begin{array}{l}\text { macro (CT) } \\
\text { CS invasion }\end{array}$ & NA & TSS & partial & $\begin{array}{c}\text { adenoma } \\
\mathrm{ACTH}_{+}\end{array}$ & 4.2 & no & NA & yes & no & yes & $\begin{array}{l}\text { AP in } \\
\text { reposition }\end{array}$ & 15 \\
\hline 9 & $6 / F$ & $2.5 \mathrm{yrs}$ & micro (CT) & NA & TSS $^{*}$ & total & $\begin{array}{l}\text { adenoma } \\
\mathrm{ACTH}_{+}\end{array}$ & $<1.2$ & yes & NA & no & no & NA & normal & 10 \\
\hline 10 & $16 / F$ & $6 \mathrm{mos}$ & $\begin{array}{l}\text { macro (CT) } \\
\text { CS invasion }\end{array}$ & NA & TSS & total & $\begin{array}{l}\text { adenoma } \\
\mathrm{ACTH}_{+}\end{array}$ & $<1.2$ & yes & NA & no & no & NA & $\begin{array}{l}\text { AP in } \\
\text { reposition, } \\
\text { DDAVP }\end{array}$ & 9 \\
\hline 12 & $9 / M$ & $1 \mathrm{yr}$ & normal (RM) & $+(\mathrm{R})$ & TSS & total & $\begin{array}{c}\text { hyperplasia, } \\
\mathrm{ACTH}_{+}\end{array}$ & $<1.2$ & yes & NA & no & no & NA & normal & 4 \\
\hline 13 & $13 / \mathrm{M}$ & 4 yrs & micro (RM) & NA & TSS & total & $\begin{array}{l}\text { adenoma } \\
\mathrm{ACTH}+\end{array}$ & $<1.2$ & yes & NA & no & no & NA & normal & 3 \\
\hline 14 & $15 / M$ & 6 yrs & normal (RM) & $+(L)$ & $\mathrm{TSS}^{*}$ & total & $\begin{array}{c}\text { hyperplasia, } \\
\mathrm{ACTH}_{+}\end{array}$ & 2.7 & no & NA & no & no & yes & normal & 2 \\
\hline 15 & $16 / F$ & $10 \mathrm{yrs}$ & micro (RM) & NA & TSS & total & $\begin{array}{l}\text { adenoma } \\
\mathrm{ACTH}_{+}\end{array}$ & 4.8 & no & NA & no & no & no & ketoconazole & 1 \\
\hline
\end{tabular}

M: male; F: female; CT: computed tomography; MR: magnetic resonance; TSS: transsphenoidal surgery; RT: radiotherapy; ADX: adrenalectomy; FW: follow-up; NA: not applicable; L: left-side gradient; R: right-side gradient; BIPSS: bilateral inferior petrosal sinus; Hyper: hypertension; DM: diabetes mellitus; Micro: microadenoma; Macro: macroadenoma; AP: anterior hypopituitarism; GH: growth hormone; CS: cavernous sinus.

${ }^{\dagger}$ Hemorrhage secondary to an anomaly in the venous sinus during sella dissection; ${ }^{\ddagger}$ Bleeding during the surgical approach; ${ }^{\S}$ Meningitis three years after the $3^{\text {rd }}$ TSS.

* Absence of sphenoid sinus aeration. 
one presented only clinical remission (case 14). It is important to point out that case number 14 presented postoperative plasma cortisol levels of $2.7 \mu \mathrm{g} / \mathrm{dL}$. All other patients presented clinical and biochemical cure after TSS and complementary treatment. As this series of patients has been collected in a long period of time ( 24 years), during which there have been several improvements in diagnosis, surgical and radiotherapic techniques, the patients were divided into two groups: operated before and after 1998. There was a remarkable improvement of percentage of surgical cure $(37.5 \%$ versus $85.7 \%)$ in the latter ten years.

All nine patients have remained cured and have required no further treatment to date (median follow-up period: 12.1 years; range: 2 to 23 years). The six remaining patients had persisted CD, with a cortisol level in excess of $300 \mathrm{nmol} / \mathrm{L}$. A second TSS was performed in four patients. Three of them, who had persistent hypercortisolemia, were treated with postoperative external-beam direct pituitary irradiation, using a 6-MV linear accelerator, with 45 Gy in 25 fractions over a period of 35 days after surgery. Bilateral adrenalectomy was performed in four patients (cases 1, 4, 6 and 7). Three patients developed Nelson's syndrome and TSS was performed in two patients (cases 6 and 7) for the third time. Postoperative radiotherapy was performed as the only complementary treatment in one patient (case 8) (Figure 1).

Hypopituitarism was observed in four patients, two of them with macroadenoma (case 8 and 10), one patient (case 4) after radiotherapy to treat Nelson's syndrome, and one patient after TSS (case 5); permanent diabetes insipidus was observed in only one patient (case $10)$ and two patients developed growth hormone deficiency (case 5 and 14). One patient (case 6) developed meningitis after the third TSS and died.

\section{DISCUSSION}

$\mathrm{CD}$ is rare in the pediatric age group $(6,11,12)$. The disease remains a complex diagnostic challenge in childhood, because many of the diagnosis criteria and definition of cure after transsphenoidal surgery are based on results obtained in adults that have been extrapolated to the pediatric population (13). In this study, the mean prediagnosis duration of symptoms was 36 months approximately half of that reported in adults $(14,15)$. This finding was consistent with other reports of pediatric CD and has been attributed to the additional symptoms of growth delay and pubertal arrest, which prompt earlier medical evaluation (13). Children with CD present with obesity, stunted growth, and mental and behavioral problems. More than one-third of patients also have hypertension. The frequencies of the symptoms found were similar to those of other published series $(5,16)$. Increased cortisol and ACTH levels, absence of diurnal variation, cortisol and ACTH response to CRH test, poor suppression of serum cortisol levels with a low dose of dexamethasone, and suppression with a high dose are considered to be key evidence for biochemical diagnosis of CD $(11,17)$.

$\mathrm{CD}$ is often due to microadenomas that may not be detectable in routine contrast-enhanced CT and MR images. The correct detection rate of corticotroph adenoma for pediatric CD ranges from $52 \%$ to $75 \%$ for $\mathrm{CT}$ and/or MR scans in the literature (5). Most of the corticotrophin adenomas are small $(<4 \mathrm{~mm})$, and their images have similar intensity to those of normal pituitary tissue, making accurate identification of the tumor site difficult $(18,19)$. Five out of these 15 patients had normal preoperative imaging; 3 of them performed only

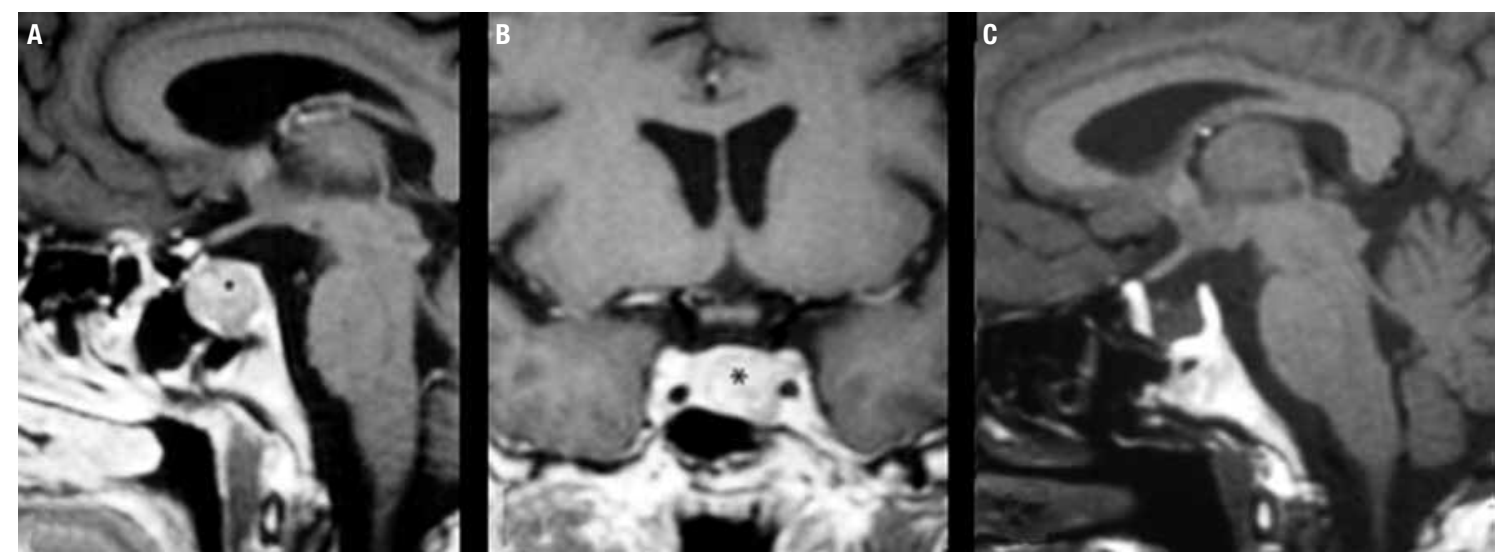

Figure 1. Case 10: (A) Sagittal and coronal (B) contrast-enhanced MR images obtained in an adolescent with Cushing's disease, demonstrating a macroadenoma (asterisk); (C) contrast-enhanced sagittal MR imaging scan of the sella four years after transsphenoidal surgery and radiotherapy, demonstrating no evidence of residual tumor. 
CT, previously MR availability. Recently, BIPSS was performed successfully in two patients with normal MR scan. This procedure proved to be a reliable method of tumor localization when CT or MR were normal, as also found by other researchers who have reported accuracy ranges of $71 \%$ to $83 \%$ for BIPSS lateralization $(5,14,16)$.

Transsphenoidal surgery is a safe and effective firstchoice treatment for the management of CD (4-6,20); it was the preferred approach for excising the adenoma in the series of the present study. However, some peculiarities are observed in the pediatric population. Since children have smaller nasal apertures, the sublabial route provided a wider corridor to access the sellar region than the direct transnasal rhinoseptal approach; this allowed the researchers to use the same nasal speculums utilized in adult patients (4). Care should be taken not to open the blades of Hardy's nasal speculum too wide within the sphenoid sinus, because the chances of injuring the carotid artery are greater in children, due to the thin surrounding bones and the narrower sphenoid sinus (10). During sellar dural opening, especially in microadenomas, care should be taken not to injure the intercavernous sinuses at the anterior and posterior sellar dural limits or the cavernous sinuses laterally, because this may cause excessive venous bleeding (13). In two cases, severe hemorrhage was observed which was secondary to an anomaly of the venous sinus observed during sella dissection in one case. In more recent cases, the endonasal route and neuronavigation have been employed with success.

In this series, even when a tumor was identified during surgery, surgical cure was not achieved in all patients. The surgical cure rate over 25-year period of this study was $60 \%$. However, there was a remarkable improvement of surgical cure $(85.7 \%)$ in the latter ten years. In the literature, surgical cure rates range from $40 \%$ to $100 \%$ (mean: $70.5 \%$ ), according to table 2 (4-6,12,13,20-28). In the present study, plasma cortisol levels considered were $<1.8 \mu \mathrm{g} / \mathrm{dL}$ during the first days after surgery for cure definition - this is a very strict criterion. Notably, the criteria for cure vary significantly in the studies from the last 25 years, justifying the variable surgical cure rates observed $(29,30)$. In addition, the experience of the neurosurgeon is another important factor. Finally, there have been several improvements in surgical techniques, such as endoscopy and neuronavigation. All these aspects have improved surgical treatment of the $\mathrm{CD}$, but also have rendered very difficult to compare patients operated 20 years ago with those operated more recently.

Although recurrence was not observed in this series, it could be due to satellite lesions $(4,16)$ adjacent to the main tumor. It is now often to proceed to a hemihypophysectomy, ensuring that an adequate normal gland is retained. Three patients showed hyperplasia of corticotroph cells, but no adenoma in the morpho-

Table 2. Overview of previously reports on the surgical outcome of the TSS in pediatric Cushing's disease

\begin{tabular}{|c|c|c|c|c|c|c|c|}
\hline Series & Number of cases & Surgical cure (\%) & Recurrence & Reoperation & Remission & Mortality & Follow-up \\
\hline Styner and cols. (11) & 15 & $14(93.3)$ & 0 & 2 & 1 & 0 & 3.6 years ( 10 months- 8.2 years) \\
\hline Buchfelder and Falbusch (21) & 15 & $13(86.6)$ & 0 & 0 & 1 & 1 & 3.1 years (1.2-11 years) \\
\hline Haddad and cols. (23) & 5 & $5(100)$ & 0 & 0 & 0 & 0 & 4.6 years ( 0.5 to 9 years) \\
\hline Partington and cols. (27) & 15 & $12(80)^{\mathrm{a}}$ & 3 & 0 & 3 & 0 & 4.5 years ( 0 to 13.5 years) \\
\hline Magiakou and cols. (6) & $37^{\mathrm{b}}$ & $35(94.5)$ & 2 & 2 & 2 & 2 & 22 months (5 to 60 months) \\
\hline Dyer and cols. (22) & 36 & $23(64)$ & 5 & 5 & 5 & 1 & 6 months to 21 years \\
\hline Weber and cols. (12) & 9 & $5(55.5)$ & 0 & 0 & 1 & 0 & 1.6 to 10.7 years \\
\hline Mathivon and cols. (25) & 16 & $9(56.2)$ & 5 & 2 & 3 & 0 & $40 \pm 35$ months \\
\hline Devoe and cols. (20) & 26 & $19(73)$ & 7 & 6 & 5 & 0 & 7.2 years ( 1.5 to 13.6 years) \\
\hline Massoud and cols. (24) & 12 & $9(75)$ & 3 & 3 & 2 & 0 & 6.8 (1 to 14 years) \\
\hline Joshi and cols. (5) & 25 & $14(56)$ & 10 & 0 & 11 & 0 & 6.9 years ( 1.3 to 12 years) \\
\hline Kanter and cols. (13) & $33^{c}$ & $22(66.6)$ & 3 & 3 & 8 & 0 & 3.6 years ( 0 to 9 years) \\
\hline Storr and cols. (28) & 27 & $16(59)$ & 0 & 0 & 0 & 0 & $7.1 \pm 5.3$ years ( 0.5 to 17.8 years) \\
\hline Mehrazin (26) & 8 & $6(75)$ & 2 & 2 & 0 & 0 & 13.4 ( 1 to 23 years) \\
\hline Das and cols. (4) & 10 & $4(40)$ & 6 & 1 & 3 & 0 & 5.3 years ( 1 to 10 years) \\
\hline Current series & 15 & $8(53.3)$ & 2 & 4 & 2 & 1 & 11 years ( 1 to 25 years) \\
\hline
\end{tabular}

${ }^{a}$ In the group of 12 patients with initial remission, 3 patients had a late recurrence; ${ }^{b}$ excluded cases operated on in another service; ${ }^{c}$ ten patients were submitted on TSS surgery in another service ${ }^{4}$. 
logic study. Among then, one patient did not achieved cure. The others have been cured in a follow-up period of four years. Pituitary hyperplasia can be defined as a non-neoplastic increase in one or more functionally distinct types of pituitary cells (31). Kovacs and cols. (32) reported a patient who present corticotroph hyperplasia and had a long-lasting remission (14 years), but CD recurred. The authors suggest that corticotroph hyperplasia may cause $\mathrm{CD}$ and the elimination of the negative inhibitory feedback effect by corticosteroids after adrenalectomy plays a role in adenoma initiation (32). Therefore, ultimate outcome analysis is critically dependent on the criteria adopted to define cure and may only be made with careful and long-term followup. Despite a clear need for uniformity in the definition of postoperative cure in $\mathrm{CD}$, there is still considerable variation in definitions between centers, making meaningful comparison of data difficult $(33,34)$.

As advocated by Trainer and cols. (19), a postoperative cortisol level of $<1.8 \mu \mathrm{g} / \mathrm{dL}$ or $50 \mathrm{nmol} / \mathrm{L}$ has been adopted as criterion of cure, based on the physiological principle that high cortisol levels will suppress normal corticotroph function, so that complete removal of a corticotroph adenoma will render the patient ACTH deficient, with low or undetectable cortisol levels. Some authors (34) have proposed that the presence of an intrasellar lesion and postoperative serum cortisol $<50 \mathrm{nmol} / \mathrm{L}$ are good predictors of cure in long term, with some degree of hypopituitarism. However, Yap and cols. (35) concluded that undetectable postoperative cortisol is not always predictive of long-term cure in an adult series.

Pituitary radiotherapy is effective for the treatment of $\mathrm{CD}$, but it is only used on patients with persisting disease after surgery; growth hormone deficiency seems to be an unavoidable complication after treatment with radiotherapy $(5,36)$. In this series, radiotherapy was performed as complementary treatment in four patients after TSS, with two of them achieving cure of CD. Recently, it has been reported that high-precision stereotactic radiosurgery (37) and gamma knife surgery (38) can effectively treat persistent or recurrent CD following TSS.

Bilateral adrenalectomy has long been considered the treatment of choice for CD in childhood. Nowadays, it still has a role, but should be reserved for patients in whom surgery and radiotherapy fail to stop the secretion of ACTH from the pituitary adenoma (25). Although adrenalectomy is the only treatment that offers an immediate control of hypercortisolism with $100 \%$ certainty, it is necessary to consider its side effects, including potential adrenal insufficiency crisis. Therefore, lifelong need for glucocorticoid and mineralocorticoid replacement therapy hyperpigmentation, elevated ACTH levels, and an enlarged sella turcica attributable to Nelson's syndrome have been described in 12 to $67 \%$ of cases $(38-41)$. In addition, there is a continued need for glucocorticoid and mineralocorticoid replacement therapy. Bilateral adrenalectomy was performed in four patients; three of them developed Nelson's syndrome and were treated with further surgery and radiotherapy. Pituitary radiotherapy at the time of adrenalectomy seems to reduce the risk of Nelson's syndrome development (41).

In conclusion, TSS remains a safe and effective primary treatment of pediatric $\mathrm{CD}$, with minimal morbidity and mortality and with a cure rate comparable to those reported in published series. However, interpretation of the results of surgery depends on the criteria adopted to define postoperative cure. Our data support the proposals of others that the goal of surgery for CD should be to render postoperative cortisol levels low or undetectable, while maintaining normal pituitary function. A neurosurgeon, who is a specialist in pituitary disease, is indicated.

Disclosure: no potential conflict of interest relevant to this article was reported.

\section{REFERENCES}

1. Savage MO, Storr HL, Chan LF, Grossman AB. Diagnosis and treatment of pediatric Cushing's disease. Pituitary. 2007;10(4):365-71.

2. Bigos ST, Somma M, Rasio E, Eastman RC, Lanthier A, Johnston $\mathrm{HH}$, et al. Cushing's disease: management by transsphenoidal pituitary microsurgery. J Clin Endocrinol Metab. 1980;50(2):348-54.

3. Chee GH, Mathias DB, James RA, Kendall-Taylor P.Transsphenoidal pituitary surgery in Cushing's disease: can we predict outcome? Clinical Endocrinol (Oxf). 2001;54(5):617-26.

4. Das NK, Lyngdoh BT, Bhakri BK, Behari S, Bhatia V, Jain VK, et al. Surgical management of pediatric Cushing's disease. Surg Neurol. 2007;67(3):251-7.

5. Joshi SM, Hewitt RJ, Storr HL, Rezajooi K, Ellamushi H, Grossman $A B$, et al. Cushing's disease in children and adolescents: 20 years of experience in a single neurosurgical center. Neurosurg. 2005;57(2):281-5.

6. Magiakou MA, Chrousos GP. Cushing's syndrome in children and adolescents: current diagnostic and therapeutic strategies. J Endocrinol Invest. 2002;25(2):181-94.

7. Liddle GW. Tests of pituitary-adrenal suppressibility in the diagnosis of Cushing's syndrome. J Clin Endocrinol Metab. 1960;20:1539-60.

8. Castro M, Moreira AC. Screening and diagnosis of Cushing's syndrome. Arq Bras Endocrinol Metab. 2007; 51(8):1191-8. 
9. Martinelli CE Jr, Sader SL, Oliveira EB, Daneluzzi JC, Moreira AC. Salivary cortisol for screening of Cushing's syndrome in children. Clin Endocrinol (Oxf). 1999;51(1):67-71.

10. Hardy J.Transphenoidal microsurgery of the normal and pathological pituitary. Clin Neurosur. 1969;16:185-217.

11. Styne DM, Grumbach MM, Kaplan SL, Wilson CB, Conte FA. Treatment of Cushing's disease in childhood and adolescence by transsphenoidal microadenomectomy. N Engl J Med. 1984;310(14):889-93.

12. Weber A, Trainer PJ, Grossman AB, Afshar F, Medbak S, Perry LA, et al. Investigation, management and therapeutic outcome in 12 cases of childhood and adolescent Cushing's syndrome. Clin Endocrinol (Oxf). 1995;43(1):19-28.

13. Kanter AS, Diallo AO, Jane JA Jr, Sheehan JP, Asthagiri AR, Oskouian RJ, et al. Single-center experience with pediatric Cushing's disease. J Neurosurg. 2005;103(5 Suppl):413-20.

14. Boggan JE, Tyrrell JB, Wilson CB. Transsphenoidal microsurgical management of Cushing's disease. Report of 100 cases. J Neurosurg. 1983;59(2):195-200.

15. Mampalam TJ, Tyrrell JB, Wilson CB. Transsphenoidal microsurgery for Cushing disease. A report of 216 cases. Ann Intern Med. 1988;109(6):487-93.

16. Fahlbusch R, Honegger J, Buchfelder M. Neurosurgical management of Cushing's disease in children. In: Savage MO, Bourguinon JP, Grossman AB, editors. Frontiers in pediatric endocrinology. Oxford: Blackwell Scientific Publications; 1994. p. 68-72.

17. Streeten DH, Faas FH, Elders MJ, DalakosTG, Voorhess M. Hypercortisolism in childhood: shortcomings of conventional diagnostic criteria. Pediatrics. 1975;56(5):797-803.

18. Marcovitz S, Wee R, Chan J, Hardy J. Diagnostic accuracy of preoperative CT scanning of pituitary prolactinomas. AJNR Am J Neuroradiol. 1988;9(1):13-7.

19. Trainer PJ, Lawrie HS, Verhelst J, Howlett TA, Lowe DG, Grossman AB. Transsphenoidal resection in Cushing's disease: undetectable serum cortisol as the definition of successful treatment. Clin Endocrinol (Oxf). 1993;38(1):73-8.

20. Devoe DJ, Miller WL, Conte FA, Kaplan SL, Grumbach MM, Rosenthal SM, et al. Long-term outcome in children and adolescents after transsphenoidal surgery for Cushing's disease. J Clin Endocrinol Metab. 1997;82(10):3196-202.

21. Buchfelder M, Fahlbusch R. Neurosurgical treatment of Cushing's disease in children and adolescents. Acta Neurochir Suppl (Wien). 1985;35:101-5.

22. Dyer EH, Civit T, Visot A, Delalande O, Derome P. Transsphenoidal surgery for pituitary adenomas in children. Neurosurgery. 1994;34(2):207-12.

23. Haddad SF, VanGilder JC, Menezes AH. Pediatric pituitary tumors. Neurosurgery. 1991;29(4):509-14.

24. Massoud AF, Powell M, Williams RA, Hindmarsh PC, Brook CG. Transsphenoidal surgery for pituitary tumours. Arch Dis Child. 1997;76(5):398-404.
25. Mathivon L, Carel JC, Coutant R, Derome P, Adamsbaum C, Bougnères $P$, et al. [Cushing disease in children and in adolescents. Therapeutic results]. Arch Pediatr. 1997;4(6):521-8.

26. Mehrazin M. Pituitary tumors in children: clinical analysis of 21 cases. Childs Nerv Syst. 2007;23(4):391-8.

27. Partington MD, Davis DH, Laws ER Jr, Scheithauer BW. Pituitary adenomas in childhood and adolescence. Results of transsphenoidal surgery. J Neurosurg. 1994;80(2):209-16.

28. Storr HL, Afshar F, Matson M, Sabin I, Davies KM, Evanson J, et al. Factors influencing cure by transsphenoidal selective adenomectomy in paediatric Cushing's disease. Eur J Endocrinol. 2005;152(6):825-33.

29. Czepielewski MA, Rollin GA, Casagrande A, Ferreira NP. Criteria of cure and remission in Cushing's disease: an update. Arq Bras Endocrinol Metab. 2007;51(2):1362-72.

30. Patil CG, Prevedello DM, Lad SP, Vance ML, Thorner MO, Katznelson $L$, et al. Late recurrences of Cushing's disease after initial successful transsphenoidal surgery. J Clin Endocrinol Metab. 2008;93(2):358-62.

31. Al-Gahtany M, Horvath E, Kovacs K. Pituitary hyperplasia. Hormones. 2003;2(3):149-58.

32. Kovacs $K$, Horvath E, Coire C, Cusimano M, Smyth H, Scheithauer $\mathrm{BW}$, et al. Pituitary corticotroph hyperplasia preceding adenoma in a patient with Nelson's syndrome. Clin Neuropathol. 2006;25(2):74-80.

33. Newell-Price J. Transsphenoidal surgery for Cushing's disease: defining cure and following outcome. Clin Endocrinol. 2002;56(1):19-21.

34. Rees DA, Hanna FW, Davies JS, Mills RG, Vafidis J, Scanlon MF. Long-term follow-up results of transsphenoidal surgery for Cushing's disease in a single centre using strict criteria for remission. Clin Endocrinol (Oxf). 2002;56(4):541-51.

35. Yap LB, Turner HE, Adams CB, Wass JA. Undetectable postoperative cortisol does not always predict long-term remission in Cushing's disease: a single centre audit. Clin Endocrinol. 2002;56(1):25-31.

36. Mahmoud-Ahmed AS, Suh JH. Radiation therapy for Cushing's disease: a review. Pituitary. 2002;5(3):175-8.

37. Jalali R, Brada M. Radiosurgery for pituitary adenoma. Crit Rev Neurosurg. 1999;9(3):167-73.

38. Weiss MH, Couldwell WT. Gamma Knife surgery for Cushing disease. J Neurosurg. 2007;106(6):976-7.

39. Hopwood NJ, Kenny FM. Incidence of Nelson's syndrome after adrenalectomy for Cushing's disease in children: results of a nationwide survey. Am J Dis Child. 1977;131(12):1353-6.

40. McArthur RG, Hayles AB, Salassa RM. Childhood Cushing disease: results of bilateral adrenalectomy. J Pediatr.1979;95(2):214-9.

41. Banasiak MJ, Malek AR. Nelson syndrome: comprehensive review of pathophysiology, diagnosis, and management. Neurosurg Focus. 2007;23(3):E13. 